\title{
Comparison of the efficacy of intrauterine lidocaine, paracervical block and oral etodolac for decreasing pain in endometrial biopsy
}

\author{
intrautein lidokain, paraservikal blok ve oral etodolak uygulamalarinın \\ endometrial biopside ağrtyı azaltmadaki etkinliklerinin karşılaştırılması
}

\author{
Ayşe Güler ${ }^{1}$, H. Güler Şahin ${ }^{1}$, Zehra Küçükaydın' ${ }^{1}$ Evrim Erdemoğlu ${ }^{2}$ \\ ' Department of Obstetrics and Gynecology, Faculty of Medicine, Yuzuncu Yil University, Van, Turkey \\ ${ }^{2}$ Department of Obstetrics and Gynecology, Faculty of Medicine, Suleyman Demirel University, Isparta, Turkey
}

\section{Abstract}

Objective: To compare the effectiveness of paracervical block, intrauterine lidocaine and oral etodolac in decreasing the pain caused by pipelle endometrial sampling. A secondary goal of this study was to determine the adverse effects and compare possible effects of these methods on pulse and blood pressure.

Material and Methods: The study was performed between April 2006 and October 2006 in the Obstetrics and Gynecology Department of Van Yüzüncü Yıl University Research Hospital. One-hundred twenty patients were randomized into four groups: 1. Group: Paracervical block was performed with $3 \mathrm{ml} 2 \%$ prilocaine solution. 2. Group: Five $\mathrm{ml}$ of $2 \%$ lidocaine solution was instilled through the endocervix into the uterine cavity. 3. Group: Subjects received $400 \mathrm{mg}$ oral etodolac tablet 1-1.5 hour before the procedure. 4. Group: No method of anesthesia was used in the control group. Endometrial sampling was performed with pipelle. Severity of pain during the procedure was scored by the subjects according to the "6-point Verbal Rating Scale (VRS)". Blood pressure and pulse rate were measured before, during and 30 minutes after the procedure.

Results: Pain scores in intrauterine lidocaine group ( $2^{\text {nd }}$ group) were found statistically significantly lower than the other three groups $(\mathrm{p}<0.05)$.

Conclusion: Intrauterine lidocaine anesthesia technique decreases pain in endometrial sampling with pipelle more efficiently than paracervical block or oral etodolac. While indication of menorrhagia and endometrial thickness more than $5 \mathrm{~mm}$ increased pain scores, intrauterine lidocaine application or paracervical block decreased the scores significantly $(\mathrm{p}<0.05)$.

(J Turkish-German Gynecol Assoc 2010; 11: 178-81)

Key words: Anesthesia, lidocaine, pain

Received: 9 October, 2010

Accepted: 14 November, 2010

\section{Özet}

Amaç: Endometrial biopsi alınmasında Pipelle kullanımının neden olduğu ağrıyı azaltmada praservikal blok, intrauterin lidokain ve oral etodolakın etkinliklerinin karşılaştırılması. Bu çalışmada ikincil olarak bu yöntemlerin yan etkileri ile nabız ve kan basıncı üzerindeki olası etkilerinin belirlenmesi ve karşılaştırılması amaçlanmıştır.

Gereç ve Yöntemler: Çalışma Nisan 2006 ve Ekim 2006 tarihleri arasında Yüzüncü Yıl Üniversitesi Arastırma Hastanesi Kadın Hastalıkları ve Dogum kliniğinde gerçekleştirildi. Yüz yirmi hasta 4 gruba randomize edildi. Birinci gruba; $3 \mathrm{ml} \% 2$ 'lik prilokain ile paraservikal blok yapıldı. İkinci gruba; intrauterin olarak $5 \mathrm{ml} \% 2$ 'lik lidokain uygulandı. Üçüncü grubtaki olgulara işlemden 1-1.5 saat önce oral olarak $400 \mathrm{mg}$ etodolak verildi. Dördüncü gruba ise herhangi bir yöntem uygulanmadı. Endometrial örnekleme pipelle endometrial örnekleme aleti ile yapıldı. İşlem esnasında duyulan ağrının şiddeti olgular tarafından "6-Nokta VRS (Verbal Rating Scale)" ye göre derecelendirildi. Kan basıncı ve nabız işlemden önce, işlem esnasında ve işlemden $30 \mathrm{dk}$ sonra ölçüldü.

Bulgular: İntrauterin lidokain grubunun (2. grup) ağrı skorları diger 3 grubun ağrı skorlarından istatistiksel olarak anlamlı şekilde daha düşük bulundu ( $\mathrm{p}>0.05)$.

Sonuç: Pipelle ile endometrial biopsi alınmasında intrauterin lidokain anestezisi, ağrıyı paraservikal blok veya oral etodolaktan daha etkin biçimde azaltmaktadır. Biopsi endikasyonunun menoraji olması ve endometrium kalınlığının 5 mm'den fazla olması ağrı skorlarını yükseltirken, intrauterin lidokain veya paraservikal blok uygulamaları skorları belirgin şekilde azaltmaktadır ( $\mathrm{p}<0.05)$.

(J Turkish-German Gynecol Assoc 2010; 11: 178-81)

Anahtar kelimeler: Anestezi, lidokain, ağrı

Geliş Tarihi: 09 Ekim 2010

Kabul Tarihi: 14 Kasım, 2010

simple, quick, safe and inexpensive methods such as Pipelle, Vabra and Z-sampler have superceded this technique. Pipelle is the most popular of these sampling devices $(1,2)$.

Although pipelle is known to be painless or to cause less pain than conventional methods of endometrial sampling, nearly half of the patients experience moderate-to-severe pain during the procedure (3). Nevertheless, there are only a few studies that have evaluated possible methods of pain-relief during endometrial biopsy using a pipelle (4). 
Paracervical block is the most common anesthetic technique which has been used for minor gynecological procedures since 1925. It has been suggested that paracervical block may reduce pain, but the evidence is not strong. The risk of anesthetic intravasation is its main disadvantage (5).

Nonsteroidal antiinflammatory drugs block prostaglandin synthesis and have been shown to be effective in the relief of mild-to-moderate pain related to various obstetrical and gynecological syndromes and procedures, such as dysmenorrhea, intrauterine device insertion, suction curettage, postpartum pain, gynecologic surgery and menorrhagia $(6,7)$.

Recent studies have investigated the use of local anesthetics (i.e., lidocaine, mepivacaine) to lessen the pain experienced during minor gynecological procedures such as endometrial biopsy and office hysteroscopy. Most, but not all, of these studies reported reduced pain during the procedure (8-10).

The main objective of the present study was to compare the effectiveness of paracervical block, intrauterine lidocaine and oral etodolac in decreasing pain caused by endometrial sampling. A secondary goal of this study was to determine the adverse effects and compare possible effects of these methods on pulse and blood pressure.

\section{Material and Methods}

The study was performed between April and October 2006 in the Obstetrics and Gynecology department of Yuzuncu Yll University Research Hospital. One-hundred twenty patients who fulfilled the inclusion criteria and required endometrial biopsy to be taken for various indications were enrolled in the study. Subjects were randomized for paracervical block ( $1^{\text {st }}$ group), intrauterine lidocaine ( $2^{\text {nd }}$ group), etodolac ( $3^{\text {rd }}$ group) and control ( $4^{\text {th }}$ group) groups. In the $1^{\text {st }}$ group, paracervical block was performed with $3 \mathrm{ml} 2 \%$ prilocaine (Citanest flacon; AstraZeneca, İstanbul, Türkiye) solution. In the $2^{\text {nd }}$ group, a blue colored feeding catheter $(2.70 \mathrm{~mm}$ in diameter) was shortened with a sterile scalpel to about $20 \mathrm{~cm}$ in length and its tip was inserted into the endometrial cavity up to $2-3 \mathrm{~cm}$ distal to the endocervix. Five $\mathrm{ml}$ of $2 \%$ lidocaine solution were instilled slowly through the catheter into the uterine cavity and the catheter was withdrawn after 3 minutes. In the 3rd group, subjects received $400 \mathrm{mg}$ oral etodolac tablet 1-1.5 hour before the procedure. In the $4^{\text {th }}$ group no methods of anesthesia was used. Endometrial sampling of all subjects was performed by the same person using the pipelle endometrial sampling device. After completion of the procedure, but before the speculum was taken out, all patients were asked to score the severity of pain they had felt during the procedure according to the "6-point Verbal Rating Scale (VRS)". Blood pressures and pulse rates of all subjects were measured before, during and 30 minutes after the procedure. All subjects were observed in the clinic during the first hour after the procedure and were asked at the end of this time if they needed additional analgesia. Endometrial tissue samples were examined in the pathology laboratory of Yuzuncu Yil University Research Hospital.

Statistical analysis of data was performed using SPSS 13.0 for Windows package programme with Student's- $t$ test, Post-hoc LSD test, Chi-square test, One-way ANOVA and Spearman correlation analysis tests.

\section{Results}

In Table 1, demographic characteristics of the subjects are demonstrated. Ages of 120 subjects included in the study were between 20-67 years and mean age was 46.1 \pm 9.3 years. Of the 120 subjects, $92(77 \%)$ were premenopausal and $28(13 \%)$ were postmenopausal. There were no statistically significant differences in age, gravidity, parity, number of living children or menopausal status of the groups $(p>0.05)$. Mean systolic blood pressure of the subjects measured before, during and 30 minutes after the procedure were $125.3 \pm 11.7 \mathrm{mmHg}$, $123.9 \pm 11.6 \mathrm{mmHg}$ and $123.2 \pm 9.9 \mathrm{mmHg}$, respectively. Mean diastolic blood pressures were $79.9 \pm 7.4 \mathrm{mmHg}, 80.6 \pm 7.6$ $\mathrm{mmHg}, 78.7 \pm 9.3 \mathrm{mmHg}$, and mean pulse rates were $83.9 \pm 7.1$ beat $/$ minute, $82.8 \pm 5.2$ beat $/$ minute and $83.8 \pm 4.2$ beat $/ \mathrm{min}$ ute, respectively. No statistically significant differences among groups were found in terms of blood pressures and pulse rates ( $>0.05)$. For blood pressures and pulse rates, there were also no clinically significant differences between measurements before and during or after the procedure $(p>0.05)$.

In Table 2, dispersion of the pain scores of four groups are showed. When pain scores of groups were compared (Table 3 ), scores in the intrauterine lidocaine group ( $2^{\text {nd }}$ group) were found statistically significantly lower than in the other three

Table 1. Demographic characteristics of the groups

\begin{tabular}{|c|c|c|c|c|c|}
\hline & $\begin{array}{l}\text { 1. Group } \\
(n=30)\end{array}$ & $\begin{array}{l}\text { 2. Group } \\
(n=30)\end{array}$ & $\begin{array}{l}\text { 3. Group } \\
(n=30)\end{array}$ & $\begin{array}{l}\text { 4. Group } \\
(n=30)\end{array}$ & $\mathbf{p}$ \\
\hline Age (year)* & $43.3 \pm 10.4$ & $44.8 \pm 8.8$ & $48.5 \pm 8.3$ & $47.8 \pm 9.2$ & $\mathrm{p}=0.099$ \\
\hline Gravidity* & $8.7 \pm 4.1$ & $7.4 \pm 3.6$ & $8.7 \pm 3.5$ & $7.6 \pm 4.4$ & $\mathrm{p}=0.364$ \\
\hline Parity* & $7.0 \pm 3.3$ & $6.2 \pm 3.4$ & $7.7 \pm 3.3$ & $6.6 \pm 3.5$ & $\mathrm{p}=0.362$ \\
\hline Abortion* & $0.6 \pm 1.0$ & $0.9 \pm 1.6$ & $0.5 \pm 0.6$ & $0.7 \pm 1.3$ & $\mathrm{p}=0.552$ \\
\hline Live child* & $5.9 \pm 3.1$ & $5.1 \pm 2.6$ & $6.6 \pm 2.35$ & $6 \pm 2.9$ & $\mathrm{p}=0.163$ \\
\hline \multicolumn{6}{|l|}{ Menopausal status } \\
\hline Premenopausal (\%) & $23(76.7)$ & $23(76.7)$ & $23(76.7)$ & $23(76.7)$ & $\mathrm{p}=1.000$ \\
\hline Postmenopausal (\%) & $7(23.3)$ & $7(23.3)$ & $7(23.3)$ & $7(23.3)$ & $\mathrm{p}=1.000$ \\
\hline
\end{tabular}


Table 2. Distribution of patients in groups according to the pain scores

\begin{tabular}{|l|c|c|c|c|c|c|c|}
\hline \multirow{2}{*}{ Groups } & \multicolumn{5}{|c|}{ PAIN SCORE } & \multirow{2}{*}{ Total } \\
\cline { 2 - 8 } & $\mathbf{0}$ & $\mathbf{1}$ & $\mathbf{2}$ & $\mathbf{3}$ & $\mathbf{4}$ & $\mathbf{5}$ & \\
\hline Paracervical block & 8 & 15 & 0 & 5 & 1 & 1 & 30 \\
\hline Intrauterine lidocaine & 13 & 8 & 8 & 0 & 0 & 1 & 30 \\
\hline Oral Etodolac & 3 & 12 & 7 & 4 & 3 & 1 & 30 \\
\hline Control & 2 & 9 & 11 & 4 & 3 & 1 & 30 \\
\hline Total & 26 & 44 & 26 & 13 & 7 & 4 & 120 \\
\hline
\end{tabular}

0 : No pain, 1: Mild pain, 2: Moderately severe pain, 3: Severe pain, 4: Very severe pain, 5 : Unbearable pain

Table 3. Comparison of groups for pain scores

\begin{tabular}{|l|l|}
\hline GROUPS & P \\
COMPARED & VALUES \\
\hline Group 1-Group 2 & $\mathbf{p}=\mathbf{0 . 0 0 4}$ \\
\hline Group 1-Group 4 & $\mathbf{p}=\mathbf{0 . 0 0 4}$ \\
\hline Group 1-Group 3 & $\mathbf{p}=0.057$ \\
\hline Group 2-Group 3 & $\mathbf{p}=\mathbf{0 . 0 1 5}$ \\
\hline Group 2-Group 4 & $\mathbf{p}=\mathbf{0 . 0 0 8}$ \\
\hline Group 3-Group 4 & $\mathbf{p}=0.911$ \\
\hline
\end{tabular}

groups $(\mathrm{p}<0.05)$. While the difference between pain scores of paracervical block ( $1^{\text {st }}$ group) and etodolac ( $3^{\text {rd }}$ group) groups, and between pain scores of etodolac and control (4 $4^{\text {th }}$ group) groups were not statistically significant $(p>0.05)$, the difference between the scores of paracervical block ( $1^{\text {st }}$ group) and control ( $4^{\text {th }}$ group) groups was statistically significant $(p=0.004)$. In ordinal regression analysis, predictors which probably affect pain scores (menopausal status, parity, endometrial thickness, indication for biopsy and type of anesthesia applied) were examined. Of these predictors, indication for endometrial biopsy, thickness of endometrium being less or more than 5 $\mathrm{mm}$ and the method of anesthesia/analgesia were all the factors which affected the pain scores. While the indication of menorrhagia $(p=0.02)$ and endometrial thickness more than $5 \mathrm{~mm}(\mathrm{p}=0.03)$ increased pain scores, intrauterine lidocaine application and paracervical block decreased the scores significantly $(\mathrm{p}<0.05)$.

There was no statistically significant difference among groups in terms of additional analgesia requirement ( $p>0.05)$. No complications occurred in any of the subjects either during or one hour after the procedure.

\section{Discussion}

In many gynecologic examinations, assessment of the endometrium is required. Traditionally, this used to be achieved by dilatation and curettage (D\&C) $(1,2)$. D\&C, which had gained wide acceptance by the end of the 1950's, has begun to be questioned after awareness of evidence-based medicine. As a result, many investigators were forced to find alternative methods.

Since this relatively expensive method, D\&C, is not excellent in diagnosis and treatment and also has some complications and problems in its acceptability by patients, many investigators tended to search for alternative methods (11-15). Pipelle is a relatively painless method that does not require dilatation and has low morbidity and $97.5 \%$ sensitivity for cancer (16). Many recent studies revealed that pipelle was preferred because of its low cost, easy transport, suitability for peripheral usage and causing less pain. We also preferred pipelle for taking endometrial biopsy in our study.

At the end of the study, a statistically significant difference was determined among groups in terms of pain scores. Although pipelle has been defined as a painless method, in a study by Trolice et al, a moderate degree of pain was reported to be felt by the patients when anesthesia was not applied during pipelle endometrial biopsy (4). Intrauterine anesthesia is a method that have been tried in different gynecologic procedures by some investigators and various data on its effectiveness have been reported. In the study by Guney et al. published in 2006, it was reported that intrauterine lidocaine could be an effective anesthetic method for removing lost IUD's (17). In their 40-patientstudy, Edelman et al. reported that $5 \mathrm{ml}$ of $4 \%$ lidocaine injected into the endometrial cavity after giving a standard paracervical block decreased the pain significantly more than a placebo in dilatation and curettage of first trimester elective abortions (18). Although these studies are different from ours in terms of material and method, they are significant as they showed that intrauterine anesthesia decreased pain in many gynecologic procedures. A limited number of studies on intrauterine topical anesthesia is available in literature and in most of these studies, the effectiveness of intrauterine anesthesia was investigated either in hysteroscopy or in hysteroscopy combined with endometrial biopsy $(5,8-10,17)$. Endometrial biopsy taken during hysteroscopy is more invasive and potentially more disturbing than only endometrial biopsy. Pain and disturbance caused by uterine distension during hysteroscopy are less responsive to the topical anesthesia (10). Considering that endometrial biopsy alone is simpler and less painful than hysteroscopy, intrauterine lidocaine is expected to prevent pain in endometrial biopsy according to these studies. In our study also, this anesthetic method was found effective.

In two different studies by Cicinelli et al., the effectiveness of intrauterine anesthesia in postmenopausal patients was investigated during diagnostic hysteroscopy and endometrial biopsy. In the first (19) of those studies, no statistically significant difference was found between intrauterine anesthesia and placebo. However in the second, which was performed with a larger number of subjects, more effective anesthesia was achieved with application of intrauterine anesthesia and this was statistically significant (10). Although both pre- and post-menopausal patients were included in our study, the second study by Cicinelli et al. supports our results.

In the study by Zupi et al., it was reported that $5 \mathrm{ml} 2 \%$ mepivacaine applied into the uterus, as in our study, effectively decreased pain in an endometrial biopsy taken during hysteroscopy (9). Chanrachakul et al. also reported that intrauterine lidocaine decreased pain in fractionated curettage without causing any complications (20). 
Lau et al. reported in two separate studies that neither paracervical block nor intrauterine anesthesia was effective in decreasing pain in hysteroscopy and endometrial biopsy compared to a placebo $(5,8)$.

Anesthetic methods were not combined in our study and the nonsteroidal antiinflammatory tablet did not provide sufficient analgesia by itself. Pain scores were similar in the etodolac tablet group and the control group where no form of anesthesia was applied.

In the study by Dogan et al., the pain decreasing effects of intrauterine lidocaine and oral naproxen sodium in endometrial biopsy with pipelle were compared with each other and with their combined usage. Pain caused by pipelle biopsy was evaluated with the $10 \mathrm{~cm}$ visual analog scale. They found that intrauterine lidocaine application combined with naproxen sodium given 1 hour before the procedure statistically significantly decreased pain. When applied separately, naproxen sodium and intrauterine lidocaine each decreased pain equally compared to the placebo, but this decrease was not significant statistically. However, when applied together, intrauterine lidocaine and naproxen sodium statistically significantly decreased pain more compared to placebo and to each of them separately (3).

Instead of naproxen, which has been tried before, we aimed to investigate the effectivness of etodolac, also a nonsteroidal antiinflammatory drug that has not been previously tried for use in endometrial biopsy with pipelle, and had a pain decreasing effect comparable to naproxen. In our study, we did not find a significant difference between the group given nonsteroidal antiinflamatory drug 1 hour before the procedure and the control group to whom no anesthetic or analgesic methods was applied. In Dogan et al.'s study also, no significant diferences was determined between the naproxen and placebo groups. Also in that study, in contrast to our findings, intrauterine lidocaine application itself was not found more effective than placebo or naproxen sodium application. However, in our study, intrauterine lidocaine in the same doses were determined to provide significant pain decrease compared to paracervical block and etodolac.

In conclusion; intrauterine lidocaine anesthesia is the anesthesia of choice for pipelle endometrial biopsy, being easily applied without pain and can provide sufficient anesthesia without causing serious complications. Intrauterine lidocaine anesthesia may be an effective method that is safely used mainly for endometrial sampling and also for various other gynecological and obstetrical procedures. It is clear that further clinical studies with larger numbers of patients are required in order to obtain more scientific data on this issue.

\section{Conflict of interest}

No conflict of interest is declared by authors.

\section{References}

1. Koonings PP, Moyer DL, Grimes DA. A randomized clinical trial comparing Pipelle and Tis-U-Trap for endometrial biopsy, Obstet Gynecol. 1990; 75: 293-5

2. Cooper J, Erickson M. Endometrial sampling tecniques in the diagnosis of abnormal uterine bleeding. Obstet Gynecol Clin North Amer. 2000; 27: 235-43.

3. Dogan E, Celiloglu M, Sarihan E, Demir A. Anesthetic effect of intrauterine lidocaine plus naproxen sodium in endometrial biopsy, Obstet Gynecol. 2004; 103: 347-51.

4. Trolice M.P, Fisburne C. Jr, McGrady S. Anesthetic efficacy of intrauterine lidocaine for endometrial biopsy: a randomized doublemasked trial, Obstet Gynecol. 2000; 95: 345-7.

5. Lau WC, Tam WH, Lo WK, Yuen PM. Paracervical anaesthesia in outpatient hysteroscopy: a randomized double-blind placebo-controlled trial. Br J Obstet Gynaecol. 1999; 106: 356-9.

6. Nagele F, Lockwood G, Magos A. Randomized placebo controlled trial of mefenamic acid for premedication at outpatient hysteroscopy: a pilot study, Br J Obstet Gynaecol. 1997; 104: 842-4.

7. Suprapto K. Reed S. Naproxen sodium for pain relief in first trimester abortion, Am J Obstet Gynecol. 1984; 150: 1000-1.

8. Lau WC, Tam WH, Lo WK, Yuen PM. A randomized double-blind placebo-controlled trial of transcervical intrauterine local anesteshia in outpatient hysteroscopy. Brit J Obstet Gynaecol. 2000; 107: 610-3.

9. Zupi E, Luciano AA, Valli E, Marconi D, Maneschi F, Romanini C. The use of topical anesthesia in diagnostic hysteroscopy and endometrial biopsy, Fertil Steril. 1995; 63: 414-6,

10. Cicinelli E, Didonna T, Ambrosi G, Schonauer LM, Fiore G, Matteo MG. Topical anesthesia for diagnostic hysteroscopy and endometrial biopsy in postmenopausal women: A randomized placebo-controlled double-blind study. Br J Obstet Gynaecol. 1997; 104: 1326-7.

11. Greeg RH. The praxeology of the office dilatation and curettage, Am J Obstet Gynecol. 1981; 140: 179-83.

12. Grimes DA. Diagnostic dilation and curettage: a reapprasial, Am J Obstet Gynecol.; 1982; 142: 1-6.

13. Hofmeister FJ. Endometrial biopsy: another look, Am J Obstet Gynecol. 1974; 118: 773-7.

14. Sandmire HF, Austin SD. Curettage as an Office procedure, Am J Obstet Gynecol. 1974; 119: 82-8.

15. Smith JJ, Schulman H. Current dilatation and curettage practice: A need for revision, Obstet Gynecol. 1985; 65: 516-8.

16. Jaber R. Detection of screening for endometrial cancer. J Fam Pract. 1988; 26: 67-72.

17. Guney M, Oral B, Mungan T. Efficacy of intrauterine lidocaine for removal of a "lost" intrauterine device: a randomized, controlled trial. Obstet Gynecol. 2006; 108: 119-23.

18. Edelman A, Nichols MD, Leclair C, Jensen T. Four percent intrauterine lidocaine infusion for pain management in first trimester abortions, Obstetrics\&Gynecology. 2006; 107: 269-75.

19. Cicinelli E, Didonna T, Fiore G, Parisi C, Matteo MG, Castrovilli G. Topical anesthesia for hysteroscopy in postmenopausal women. J Am Assoc Gynecol Laparosc. 1996; 4: 9-12.

20. Chanrachakul B, Liittanasombut P, O-Prasetsawat P. Lidocaine versus plain saline for pain relief in fractional curettage: A randomized controlled trial. Obstet Gynecol. 2001; 98: 592-5. 